\title{
Effect of Organic Manures in Conjunction with Inorganic Fertilizers on FCV Tobacco Productivity
}

\author{
C. Chandrasekhararao*, D. Damodar Reddy, M. Anuradha, \\ S.V. Krishna Reddya and J. Poorna Bindu
}

ICAR- Central Tobacco Research Institute, Rajahmundry, Andhra Pradesh, 533 105, India

*Corresponding author

\section{A B S T R A C T}

Tobacco is one of the important commercial cash crops grown in India and plays a vital role in the Indian economy. Yield and quality improvement of FCV tobacco through soil

\section{Keywords}

FCV tobacco, FYM, Tata Geo Green, Nutrient uptake

\section{Article Info}

Accepted: 04 June 2018 Available Online: 10 July 2018 health management is essential for sustainable FCV tobacco production. In view of the scarcity in organic manures, by product of sugarcane industry (Tata geo green) was evaluated as an organic manure source for FCV tobacco in the light textured irrigated Alfisols. Field experiments were conducted during 2012-15, in split plot design with five main treatments, (no farm yard manure, FYM $5 \mathrm{t} \mathrm{ha}^{-1}$, FYM $10 \mathrm{t} \mathrm{ha}^{-1}$, TGG 1t ha $\mathrm{han}^{-1} \mathrm{t}$ $\mathrm{ha}^{-1}$ ) and four sub-plots (No fertilizer, $50 \%$ of recommended dose of fertilizer (RDF), $75 \%$ RDF and $100 \%$ RDF) replicated four times. Results revealed that application of $100 \%$ and $75 \%$ RDF showed significantly higher green leaf yield, cured leaf yield and grade index over 50\% RDF and control. Application of $10 \mathrm{t} \mathrm{ha}^{-1}$ FYM showed highest green leaf yield, cured leaf yield, nutrient uptake and grade index compared to other organic manures. Application of $100 \%$ RDF has recorded significantly higher N, P and K uptake. Based on the nutrient uptake and yield it can be concluded that among the sources, FYM $10 \mathrm{t} \mathrm{ha}^{-1}$ was superior to TGG. In the event of non-availability of FYM, TGG $\left(1 \mathrm{tha}^{-1}\right)$ can be used as a source of organic manure.

\section{Introduction}

Majority of the Indian soils are inherently poor in nutrient supply due to their geographic location in the sub-tropical/tropical climate that does not encourage maintenance and accretion of soil organic matter content (Dwivedi et al., 2016). In FCV tobacco, the application of organic manures is essential for managing soil health, increasing yields (10$15 \%$ ), and also to impart required flavour and taste (Krishnamurthy et al., 2007). Farm yard manure/ green manure is the recommended organic sources for FCV tobacco production in light textured soils. In view of scarcity for FYM, there is a need to find out an alternative source for FCV tobacco. As organic manures alone will not meet the nutritional requirement due to their limited availability and required in bulk due to low nutrient per cent, chemical fertilizers need to apply along with organic manures. Tata geo green by Rallis India. Ltd. 
is a pressmud along with sugarcane bagasse and broiler ash treated with microbial cultured spent wash which is dried. (Chandrsekhara Rao et al., 2016). The major causes for low crop yields are due to the low organic matter content as well as poor nutrient status of soils. Hence, maintenance of soil fertility is a prerequisite for long-term sustainable agriculture where organic manuring can play a vital role in the sustenance of soil fertility and crop production (Jablonska, 1990). The aim of this study is evaluation of tata geo green as an alternative source to FYM by examining its effect along with chemical fertilizers on FCV tobacco yield, nutrient uptake and quality.

\section{Materials and Methods}

A field experiment was conducted during rabi for three consecutive years (2012-15) at the, ICAR-Central Tobacco Research Institute, Regional Station, Jeelugumilli, West Godavari district, Andhra Pradesh, on sandy loam soils, slightly acidic ( $\mathrm{pH} 5.90)$, low in soluble salts $\left(0.12 \mathrm{dSm}^{-1}\right)$, organic carbon $(0.18 \%)$, high in available phosphorus (38.4 $\left.\mathrm{kg} \mathrm{ha}^{-1}\right)$, and medium in available potassium $(146.2 \mathrm{~kg}$ $\mathrm{ha}^{-1}$ ). The experiment was laid out in a split plot design with five main treatments (No farm yard manure (FYM), FYM 5 t/ha, FYM 10 t/ha, Tata Geo Green (TGG) 1 t/ha and TGG $2 \mathrm{t} / \mathrm{ha}$ ), four sub-plot treatments (No fertilizers, 50\% RDF, 75\% RDF and 100\% RDF i.e. 115: 60: $120 \mathrm{~kg} \mathrm{~N}: \mathrm{P}_{2} \mathrm{O}_{5}: \mathrm{K}_{2} \mathrm{O} / \mathrm{ha}$ ) replicated 4 times, with test variety Kanchan. Tobacco seedlings (60 days old) were transplanted at $100 \times 60 \mathrm{~cm}$ spacing. FYM and TGG were applied before planting. Fertilizer sources for $\mathrm{N}, \mathrm{P}$ and $\mathrm{K}$ were Calcium Ammonium Nitrate, Di ammonium phosphate, and Sulphate of potash, respectively and were applied in three splits at 10, 25-30 and 45 days after transplanting. All the recommended practices were followed for raising the crop. The observations viz., green leaf yield (GLY), cured leaf yield (CLY) and grade index (GI) were recorded. In order to assess the quality parameter changes in different leaf positions ( $\mathrm{P}, \mathrm{X}$ and $\mathrm{L}$ ), the cured leaf samples were collected from P (bottom), X (middle) and $\mathrm{L}$ (top) positions, dried, powdered and were estimated for chemical quality, viz. nicotine, reducing sugars (Harvey et al., 1969) and chlorides (Hanumantharao et al., 1980). The composite samples (plant samples i.e. leaf, stem and root) were analyzed for nutrient concentration $\mathrm{N}, \mathrm{P}$ and $\mathrm{K}$ using standard methods (Jackson, 1976), for computation of nutrient uptake. Soil samples were collected after completion of the experiment to study the changes in soil fertility.

\section{Results and Discussion}

\section{Yield parameters}

The economic product being the leaf, they are harvested as and when matured at regular intervals for about 8-10 times. Pooled analysis of three years (2012-15) revealed that by application of different organic manures by soil application significantly influenced green leaf yield (GLY). Green leaf yield in different organic manures ranged from 6781 to $8424 \mathrm{~kg}$ $\mathrm{ha}^{-1}$ (Table 1). Among the different organic manures, FYM application @ $10 \mathrm{t} \mathrm{ha}^{-1}$ showed significantly higher yield $\left(8424 \mathrm{~kg} \mathrm{ha}^{-1}\right)$ over FYM $5 \mathrm{t} \mathrm{ha}^{-1}$, TGG $1 \mathrm{t} \& 2 \mathrm{tha}^{-1}$. Increase in fertilizer doses over organic manures increased the green leaf yield significantly. Application of $100 \%$ RDF recorded the maximum green leaf yield of tobacco with $10540 \mathrm{~kg} \mathrm{ha}^{-1}$. The green leaf yield was found lower in no fertilizers treatment $(3722 \mathrm{~kg}$ $\mathrm{ha}^{-1}$ ). Cured leaf yield was also significantly influenced by the different organic manures and chemical fertilizers. Cured leaf yield of FCV tobacco ranged from $1431 \mathrm{~kg} \mathrm{ha}^{-1}$ to $1718 \mathrm{~kg} \mathrm{ha}^{-1}$ (Table 1). Among different organic manures treatments, the maximum and minimum cured leaf yield with 1781 and 1431 $\mathrm{kg} \mathrm{ha}^{-1}$ were recorded in FYM $10 \mathrm{t} \mathrm{ha}^{-1}$ and no 
OM, respectively. Application of FYM at $10 \mathrm{t}$ $\mathrm{ha}^{-1}$ showed significantly higher cured leaf yield compared to TGG at $1 \& 2 \mathrm{t} \mathrm{ha}^{-1}$ and also FYM at 5t c. Among different chemical fertilizer doses highest cured leaf yield was registered in $100 \% \mathrm{RDF}$ and was followed similar trend with the green leaf yield. Cured leaf in control plot where no organic manure applied showed significantly lower yield compared to other organic manures. Progressive increase in fertilizer doses over organic manures increased the yield significantly. Higher yields with farm yard manure Application of farmyard manure could be owing to higher quantity of nutrients supplied at $10 \mathrm{t} \mathrm{ha}^{-1}$ and sustained supply of nutrients through rapid mineralisation from farmyard manure, which might have met the nutrient requirement of crop over a long period at the critical stage. Muthuswamy et al., 1990 reported that balanced application of NPK in conjunction with FYM produced the highest yield of ragi, maize and cowpea. Tobacco is cultivated in the same piece of land over years, there is a possibility of low leachable nutrients in these sandy soils. Hence, application of organic manures is necessary which helps in better aggregation capacity, along with nutrients supply and better moisture holding capacity. Addition of the organic manures will maintain favourable soil $\mathrm{pH}$ for nutrient availability, apart from maintaining soil buffering capacity. Application of FYM combined with inorganic fertilizers improved the growth and yield of maize which is attributed to greater soil water content and higher nutrient availability compared to control treatment (Chiroma et al., 2006). Zhang et al., (2011) reported that the grain yield (pooled from 5 sites) under the inorganic $\mathrm{N}, \mathrm{P}$, and $\mathrm{K}$ along with manure fertilization was increased by 14 percent in wheat and 19 percent in maize compared to the inorganic NPK fertilization alone. Sumathy, et al., 2007 reported that favourable influence of FYM in improving the soil physical properties, soil moisture content thereby the improved nutrient availability from the soil, which might have helped in increasing the number of branches per plant, nodules per plant, dry matter, highest yield at the rate of $10 \mathrm{t} \mathrm{ha}^{-1}$ followed by $5 \mathrm{t} \mathrm{ha}^{-1}$. Khan et al., 2009 reported the higher yields in FCV tobacco FYM treatments, could also be attributed to improved uptake of nutrients, through higher nutrient availability.

Increase in fertilizer dose over the organic manures increased the grade index significantly. All the organic manures showed significantly higher grade index over control Application of $100 \%$ RDF showed significantly higher grade index. FYM $5 \mathrm{t}^{-} \mathrm{C}^{-}$ 1, TGG 1 and $2 \mathrm{t} \mathrm{ha}^{-1}$ being at par showed significantly lower grade index compared to FYM $10 \mathrm{t} \mathrm{ha}^{-1}$. Seasons significantly influenced the yield parameters (Green Leaf yield, cured leaf yield and grade Index). Cured leaf yield and Grade index in 2013-14 seasons was significantly higher compared to 2012-13 and 2014-15 seasons.

Shekoyan (1970) reported that increased application of FYM increased the percentage of bright grades in FCV tobacco, decreased the nitrogenous compounds and increased the carbohydrate content of the leaf. Krishnamurthy et al (1972) reported the beneficial effect of continuous application of organic manure (10 years) in improving yield and quality.

\section{Nutrient uptake}

Total nutrient (N, P \& K) uptake was computed by the sum of the uptake in individual plant parts (Lamina, mid rib, stem and root). In case of lamina and midrib the uptake in different plant positions was determined separately and total uptake was computed (Table 2 and Fig. 1-3). 
Total $\mathrm{N}$ uptake ranged from 37.7 to $47.6 \mathrm{~kg}$ $\mathrm{ha}^{-1}$ among the organic manures, highest $\mathrm{N}$ uptake was found in FYM $10 \mathrm{t} \mathrm{ha}^{-1}$ with 47.6 $\mathrm{kg} \mathrm{ha}^{-1}$. Nitrogen uptake was significantly low when there is no organic manure. FYM $5 \mathrm{t} \mathrm{ha}^{-1}$ and TGG $2 \mathrm{t} \mathrm{ha}^{-1}$ being at par showed significantly lower uptake compared to FYM $10 \mathrm{t} \mathrm{ha}^{-1}$. Seasons showed significant variation in $\mathrm{N}$ uptake. Nitrogen uptake in 2014-15 season was significantly low compared to 2012-13 and 2013-14 seasons. Increase in fertilizer doses over the organic manures increased the nitrogen uptake. Nitrogen plays an important role in tobacco production. Nutrient uptake by the plant is positively correlated with the dry matter production. With increase in yield of crop the nutrient uptake also increases. Increased level of nutrients to an optimum dose usually results in complete nutrition, improves the total dry weight of the plant, root growth which inturn increases the nutrient uptake and also yield of crop. Application of organic manures like FYM, filter press cake, or pig manure was found to increase yield of tobacco (Gopalachari, 1984). Application of organic manures significantly influenced the phosphorus uptake compared to no manure. FYM $10 \mathrm{t} \mathrm{ha}^{-1}$ showed significantly higher ' $\mathrm{P}$ ' uptake compared to TGG (1\&2 t/ha) and FYM $5 \mathrm{t} / \mathrm{ha}$. Increase in fertilizer doses increased the 'P' uptake. Seasons significantly influence the 'P' uptake. 'P' uptake in 2013-14 season was significantly higher compared to other seasons. Increase in fertilizer dose over the organic manures significantly increased the potassium uptake. Highest potassium uptake was found in $100 \%$ RDF. Organic manures significantly influenced potassium uptake compared to no manure application. Application of $10 \mathrm{t} / \mathrm{ha}$ of FYM showed significantly higher potassium uptake. The Interactions between the organic manures and fertilizer doses is not significant. Among different organic manures highest total uptake of $\mathrm{N}, \mathrm{P}$ and $\mathrm{K}\left(47.6,9.3\right.$ and $53.5 \mathrm{~kg} \mathrm{ha}^{-1}$, respectively) was recorded with incorporation of FYM $10 \mathrm{t} \mathrm{ha}^{-1}$. Among different fertilizer doses highest total uptake of N, P and K (62.7, 10.8 and $67.5 \mathrm{~kg} \mathrm{ha}^{-1}$, respectively) was recorded with $100 \%$ RDF. The increase in NPK uptake by tobacco with FYM and $100 \%$ RDF may be due to the improvement of soil environment which encouraged proliferation of roots resulting in more absorption of water and nutrients from larger area and depth. The highest nutrient uptake with organic manure might be attributed to solubilisation of native nutrients, chelation of complex intermediate organic molecules produced during decomposition of added organic manures, their mobilization and accumulation of different nutrients in different plant parts (Chesti et al., 2015). Rao, et al., 2009 reported that nutrient uptake and fibre quality parameters of cotton were influenced by integrated supply of organic and inorganic sources. Application of FYM along with chemical fertilizers has resulted in increase in $\mathrm{N}, \mathrm{P}, \mathrm{K}$ uptake of rice (Gopi et al., 2015). Increasing levels of inorganic fertilizers either individually or in combination with FYM produced an overall beneficial effect on the nutrient content of $\mathrm{N}, \mathrm{P}$ and $\mathrm{K}$. The contribution of the macronutrient from the inorganic fertilizers and FYM would have resulted in the enhanced nutrient availability leading to increased nutrient uptake.

\section{Quality parameters}

Pooled analysis of chemical quality parameters viz., nicotine, sugars and chlorides during 2012-2015 was computed and presented in tables 3-5. Nicotine the principal alkaloid present in tobacco was not significantly influenced due to application of FYM/TGG and their respective doses. However increase in plant position ( $\mathrm{P}$ to $\mathrm{L}$ ) increase the nicotine content. Nitrogen is the most limiting nutrient in the sandy and low organic matter soils. 
Table.1 Effect of different organic manures in conjunction with chemical fertilizers on yield parameters ( $\mathrm{kg} / \mathrm{ha}$ ) of FCV tobacco (Var. Kanchan) grown under irrigated Alfisols

\begin{tabular}{|c|c|c|c|}
\hline Treatments & Green Leaf Yield & Cured Leaf Yield & Grade Index \\
\hline \multicolumn{4}{|l|}{ Main Plots } \\
\hline No OM & 6781 & 1431 & 1108 \\
\hline FYM 5 t/ha & 8014 & 1588 & 1243 \\
\hline FYM $10 \mathrm{t} / \mathrm{ha}$ & 8424 & 1718 & 1322 \\
\hline TGG $1 \mathrm{t} / \mathrm{ha}$ & 7895 & 1584 & 1236 \\
\hline TGG 2 t /ha & 8085 & 1643 & 1279 \\
\hline SEm \pm & 97.4 & 28.4 & 17.6 \\
\hline CD at $5 \%$ & 284.1 & 82.8 & 51.5 \\
\hline CV\% & 17.46 & 10.7 & 8.55 \\
\hline \multicolumn{4}{|l|}{ Sub-Plots } \\
\hline No RDF & 3722 & 788 & 622 \\
\hline $50 \%$ RDF & 7790 & 1644 & 1291 \\
\hline $75 \%$ RDF & 9307 & 1881 & 1460 \\
\hline $100 \%$ RDF & 10540 & 2058 & 1579 \\
\hline SEm \pm & 168.6 & 49.1 & 30.6 \\
\hline CD at $5 \%$ & 467.4 & 136.1 & 84.7 \\
\hline CV\% & 7.45 & 9.47 & 10.4 \\
\hline \multicolumn{4}{|l|}{ Seasons } \\
\hline 2012-13 & 7949 & 1486 & 1118 \\
\hline 2013-14 & 8045 & 1793 & 1362 \\
\hline 2014-15 & 7524 & 1500 & 1233 \\
\hline SEm \pm & 176.7 & 45.6 & 39.9 \\
\hline CD at $5 \%$ & NS & 157.6 & 138.2 \\
\hline CV\% & 7.88 & 22.2 & 25.0 \\
\hline MXS Interaction & NS & NS & NS \\
\hline
\end{tabular}


Table.2 Effect of different organic manures in conjunction with chemical fertilizers on Nutrient (N,P and K) uptake (kg/ha) of FCV tobacco (Var. Kanchan) grown under irrigated Alfisols

\begin{tabular}{|c|c|c|c|}
\hline Treatments & $\mathrm{N}$ & $\mathrm{P}$ & $\mathrm{K}$ \\
\hline \multicolumn{4}{|l|}{ Main Plots } \\
\hline No OM & 37.7 & 6.8 & 39.2 \\
\hline FYM 5 t /ha & 43.1 & 7.9 & 48.4 \\
\hline FYM $10 \mathrm{t} / \mathrm{ha}$ & 47.6 & 9.3 & 53.5 \\
\hline TGG 1 t /ha & 39.3 & 7.7 & 50.8 \\
\hline TGG 2 t /ha & 43.1 & 8.2 & 53.2 \\
\hline $\mathrm{SEm} \pm$ & 0.95 & 0.20 & 0.99 \\
\hline CD at $5 \%$ & 2.76 & 0.58 & 2.89 \\
\hline CV\% & 13.5 & 15.0 & 12.1 \\
\hline \multicolumn{4}{|l|}{ Sub-Plots } \\
\hline No RDF & 14.3 & 3.9 & 23.8 \\
\hline $50 \%$ RDF & 40.2 & 7.8 & 46.1 \\
\hline $75 \%$ RDF & 51.4 & 9.4 & 58.6 \\
\hline $100 \%$ RDF & 62.7 & 10.8 & 67.5 \\
\hline $\operatorname{SEm} \pm$ & 1.64 & 0.35 & 1.72 \\
\hline CD at $5 \%$ & 4.54 & 0.96 & 4.76 \\
\hline CV\% & 10.2 & 10.8 & 12.7 \\
\hline \multicolumn{4}{|l|}{ Seasons } \\
\hline 2012-13 & 45.4 & 5.6 & 36.1 \\
\hline 2013-14 & 44.8 & 10.2 & 52.9 \\
\hline 2014-15 & 36.2 & 8.1 & 58.0 \\
\hline SEm \pm & 0.68 & 0.38 & 1.34 \\
\hline CD at $5 \%$ & 2.4 & 1.32 & 4.64 \\
\hline CV\% & 12.6 & 37.1 & 21.2 \\
\hline MXS Interaction & NS & NS & NS \\
\hline
\end{tabular}


Table.3 Effect of different organic manures in conjunction with chemical fertilizers on nicotine content (\%) of FCV tobacco (Var. Kanchan) grown under irrigated Alfisols (Pooled data)

\begin{tabular}{|c|c|c|c|}
\hline Treatment & $\mathrm{P}$ & $X$ & $\mathrm{~L}$ \\
\hline \multicolumn{4}{|l|}{ Main Plots } \\
\hline No OM & 1.10 & 1.39 & 1.43 \\
\hline FYM 5 t /ha & 1.05 & 1.30 & 1.34 \\
\hline FYM $10 \mathrm{t} / \mathrm{ha}$ & 1.10 & 1.32 & 1.39 \\
\hline TGG 1 t /ha & 1.06 & 1.26 & 1.25 \\
\hline TGG $2 \mathrm{t} / \mathrm{ha}$ & 1.05 & 1.24 & 1.27 \\
\hline SEm \pm & 0.03 & 0.05 & 0.05 \\
\hline $\mathrm{CD}$ at $5 \%$ & NS & NS & NS \\
\hline $\mathrm{CV} \%$ & 18.7 & 22.1 & 21.1 \\
\hline \multicolumn{4}{|l|}{ Sub Plots } \\
\hline No RDF & 0.78 & 0.99 & 1.04 \\
\hline $50 \%$ RDF & 1.00 & 1.16 & 1.23 \\
\hline $75 \%$ RDF & 1.15 & 1.40 & 1.41 \\
\hline $100 \% \mathrm{RDF}$ & 1.35 & 1.66 & 1.67 \\
\hline SEm \pm & 0.06 & 0.08 & 0.08 \\
\hline $\mathrm{CD}$ at $5 \%$ & 0.16 & 0.23 & 0.23 \\
\hline $\mathrm{CV} \%$ & 15.0 & 14.9 & 15.9 \\
\hline \multicolumn{4}{|l|}{ Seasons } \\
\hline $2012-13$ & 1.22 & 1.94 & 1.29 \\
\hline 2013-14 & 0.786 & 1.06 & 1.72 \\
\hline $2014-15$ & 1.204 & 0.91 & 1.02 \\
\hline SEm \pm & 0.04 & 0.04 & 0.09 \\
\hline $\mathrm{CD}$ at $5 \%$ & 0.15 & 0.15 & 0.31 \\
\hline $\mathrm{CV} \%$ & 31.7 & 25.9 & 51.7 \\
\hline MXS & NS & NS & NS \\
\hline
\end{tabular}


Table.4 Effect of different organic manures on reducing sugars content (\%) of FCV tobacco (Var. Kanchan) grown under irrigated Alfisols (Pooled data)

\begin{tabular}{|c|c|c|c|}
\hline Treatment & $\mathrm{P}$ & $\mathrm{X}$ & $\mathrm{L}$ \\
\hline \multicolumn{4}{|l|}{ Main Plots } \\
\hline No OM & 18.6 & 21.3 & 21.4 \\
\hline FYM 5 t /ha & 17.7 & 20.3 & 21.7 \\
\hline FYM 10 t /ha & 18.0 & 21.1 & 22.1 \\
\hline TGG $1 \mathrm{t} / \mathrm{ha}$ & 17.9 & 21.3 & 22.4 \\
\hline TGG $2 \mathrm{t} / \mathrm{ha}$ & 17.4 & 20.6 & 21.8 \\
\hline $\mathrm{SEm} \pm$ & 0.41 & 0.38 & 0.41 \\
\hline $\mathrm{CD}$ at $5 \%$ & NS & NS & NS \\
\hline $\mathrm{CV} \%$ & 13.8 & 10.9 & 11.2 \\
\hline \multicolumn{4}{|l|}{ Sub Plots } \\
\hline No RDF & 19.6 & 21.3 & 23.2 \\
\hline $50 \% \mathrm{RDF}$ & 19.5 & 22.5 & 22.3 \\
\hline $75 \%$ RDF & 17.4 & 21.0 & 21.5 \\
\hline $100 \% \mathrm{RDF}$ & 15.3 & 19.0 & 20.5 \\
\hline SEm \pm & 0.72 & 0.66 & 0.71 \\
\hline CD at $5 \%$ & 1.98 & 1.83 & 1.96 \\
\hline CV\% & 12.7 & 9.5 & 7.8 \\
\hline \multicolumn{4}{|l|}{ Seasons } \\
\hline 2012-13 & 18.6 & 19.1 & 18.0 \\
\hline 2013-14 & 18.7 & 20.5 & 23.3 \\
\hline 2014-15 & 16.5 & 23.3 & 24.3 \\
\hline SEm \pm & 1.28 & 0.38 & 0.54 \\
\hline CD at $5 \%$ & NS & 1.33 & 1.88 \\
\hline CV\% & 55.5 & 14.2 & 19.3 \\
\hline MXS & NS & NS & NS \\
\hline
\end{tabular}


Table.5 Effect of different organic manures on chlorides content (\%) of FCV tobacco (Var. Kanchan) grown under irrigated Alfisols (Pooled data)

\begin{tabular}{|c|c|c|c|}
\hline Treatment & $\mathbf{P}$ & $\mathbf{X}$ & $\mathbf{L}$ \\
\hline \multicolumn{4}{|l|}{ Main Plots } \\
\hline No OM & 1.02 & 1.04 & 0.91 \\
\hline FYM 5 t/ha & 1.08 & 0.98 & 0.82 \\
\hline FYM 10 t /ha & 1.11 & 1.06 & 0.87 \\
\hline TGG $1 \mathrm{t} / \mathrm{ha}$ & 1.23 & 1.13 & 0.89 \\
\hline TGG 2 t /ha & 1.50 & 1.29 & 0.92 \\
\hline SEm \pm & 0.05 & 0.04 & 0.03 \\
\hline CD at $5 \%$ & 0.16 & 0.10 & NS \\
\hline CV\% & 27.7 & 19.1 & 20.8 \\
\hline \multicolumn{4}{|l|}{ Sub Plots } \\
\hline No RDF & 1.50 & 1.58 & 1.13 \\
\hline $50 \%$ RDF & 1.12 & 0.95 & 0.88 \\
\hline $75 \%$ RDF & 1.07 & 0.96 & 0.79 \\
\hline $100 \%$ RDF & 1.07 & 0.91 & 0.73 \\
\hline SEm \pm & 0.09 & 0.06 & 0.05 \\
\hline CD at $5 \%$ & 0.26 & 0.17 & 0.15 \\
\hline CV\% & 16.8 & 18.2 & 19.3 \\
\hline \multicolumn{4}{|l|}{ Seasons } \\
\hline 2012-13 & 1.23 & 1.42 & 1.07 \\
\hline 2013-14 & 1.28 & 0.94 & 0.84 \\
\hline 2014-15 & 1.07 & 0.94 & 0.73 \\
\hline SEm \pm & 0.03 & 0.06 & 0.05 \\
\hline CD at $5 \%$ & 0.09 & 0.20 & 0.18 \\
\hline CV\% & 16.3 & 39.9 & 46.7 \\
\hline MXS & SIG* & SIG* & $\mathrm{SiG}^{*}$ \\
\hline
\end{tabular}


Table.6 Effect of different organic manure treatments on post-harvest soil properties

\begin{tabular}{|c|c|c|c|c|c|c|c|c|c|c|c|c|c|}
\hline \multirow{2}{*}{$\begin{array}{l}\text { S. } \\
\text { No }\end{array}$} & \multirow[t]{2}{*}{ Treatments } & \multicolumn{2}{|c|}{$\mathrm{pH}$} & \multicolumn{2}{|c|}{$\mathrm{EC}(\mathrm{d} S / \mathrm{m})$} & \multicolumn{2}{|c|}{ Chlorides (ppm) } & \multicolumn{2}{|c|}{$\mathrm{OC}(\%)$} & \multicolumn{2}{|c|}{ Avail P (kg/ha) } & \multicolumn{2}{|c|}{ Avail K (kg/ha) } \\
\hline & & 0-9"' & $9-18 "$ & 0-9"' & 9-18" & 0-9" & 9-18" & 0-9"' & 9-18" & 0-9"' & 9-18" & 0-9"' & 9-18" \\
\hline \multicolumn{14}{|c|}{ Main Plots } \\
\hline 1 & No OM & 5.93 & 5.54 & 0.06 & 0.07 & 18.50 & 17.2 & 0.17 & 0.21 & 22.6 & 67.10 & 93.8 & 213.3 \\
\hline 2 & FYM 5 t /ha & 6.12 & 5.75 & 0.07 & 0.08 & 17.83 & 15.2 & 0.17 & 0.21 & 34.0 & 83.1 & 105.8 & 224.5 \\
\hline 3 & FYM 10 t /ha & 6.12 & 5.80 & 0.07 & 0.08 & 18.0 & 17.0 & 0.16 & 0.21 & 39.6 & 88.85 & 110.9 & 226.3 \\
\hline 4 & TGG $1 \mathrm{t} / \mathrm{ha}$ & 6.03 & 5.64 & 0.06 & 0.07 & 17.3 & 18.7 & 0.16 & 0.20 & 37.3 & 72.15 & 114.9 & 227.4 \\
\hline \multirow[t]{3}{*}{5} & TGG $2 \mathrm{t} / \mathrm{ha}$ & 6.22 & 5.81 & 0.06 & 0.08 & 16.3 & 15.2 & 0.15 & 0.22 & 34.4 & 74.49 & 131.2 & 253.3 \\
\hline & SEm \pm & 0.10 & 0.08 & -- & - & 1.16 & 2.48 & 0.01 & 0.01 & 3.23 & 12.6 & 7.47 & 13.3 \\
\hline & $\mathrm{CD}$ at $5 \%$ & NS & 0.27 & NS & NS & NS & NS & NS & NS & NS & NS & 23.9 & NS \\
\hline \multicolumn{14}{|c|}{ Sub-Plots } \\
\hline 1 & No RDF & 6.29 & 5.89 & 0.07 & 0.08 & 17.3 & 17.2 & 0.15 & 0.21 & 28.3 & 66.3 & 111.6 & 217.7 \\
\hline 2 & $50 \% \mathrm{RDF}$ & 6.12 & 5.78 & 0.06 & 0.07 & 18.5 & 17.5 & 0.15 & 0.20 & 30.8 & 87.0 & 104.4 & 225.0 \\
\hline 3 & $75 \% \mathrm{RDF}$ & 6.05 & 5.57 & 0.07 & 0.07 & 16.1 & 17.2 & 0.15 & 0.22 & 37.8 & 70.1 & 121.3 & 228.5 \\
\hline \multirow[t]{4}{*}{4} & $100 \% \mathrm{RDF}$ & 5.87 & 5.59 & 0.06 & 0.07 & 18.4 & 14.7 & 0.19 & 0.21 & 45.4 & 67.5 & 107.9 & 244.7 \\
\hline & SEm \pm & 0.07 & 0.11 & - & - & 1.37 & 1.57 & 0.01 & 0.01 & 2.68 & 6.30 & 9.96 & 7.93 \\
\hline & $\mathrm{CD}$ at $5 \%$ & 0.18 & NS & NS & NS & NS & NS & 0.03 & NS & 7.44 & NS & NS & NS \\
\hline & Interaction (MXS) & NS & NS & NS & NS & NS & NS & NS & NS & NS & NS & NS & NS \\
\hline
\end{tabular}


Figure.1 Effect of different organic manures on N-uptake of FCV tobacco

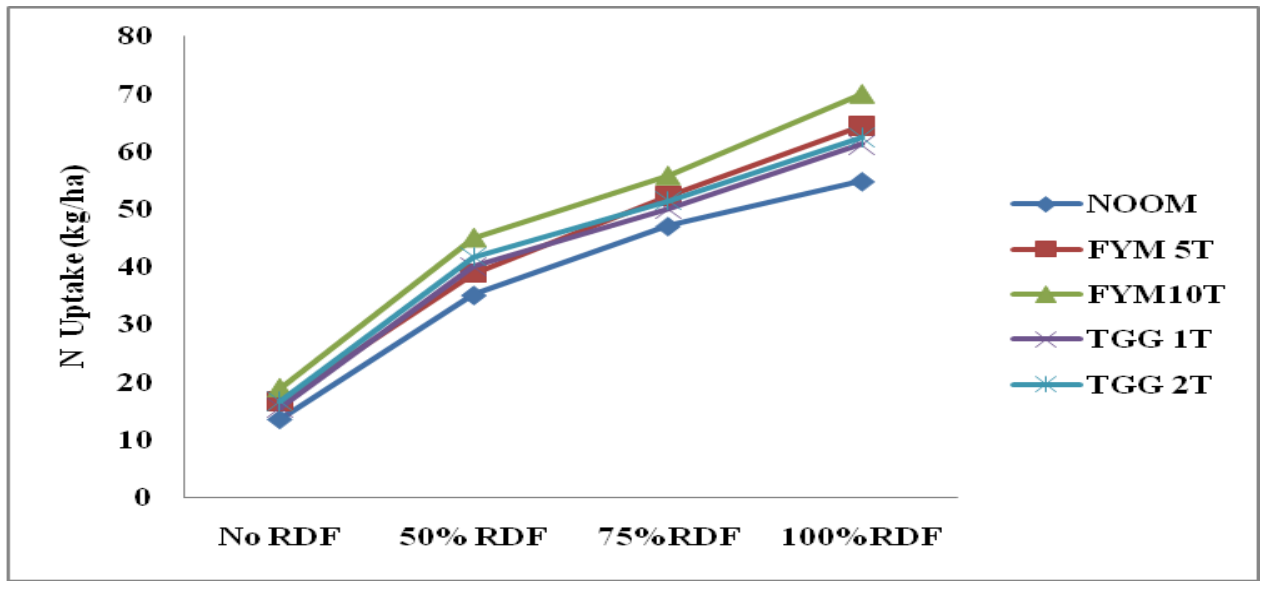

Figure.2 Effect of different organic manures on P-uptake of FCV tobacco

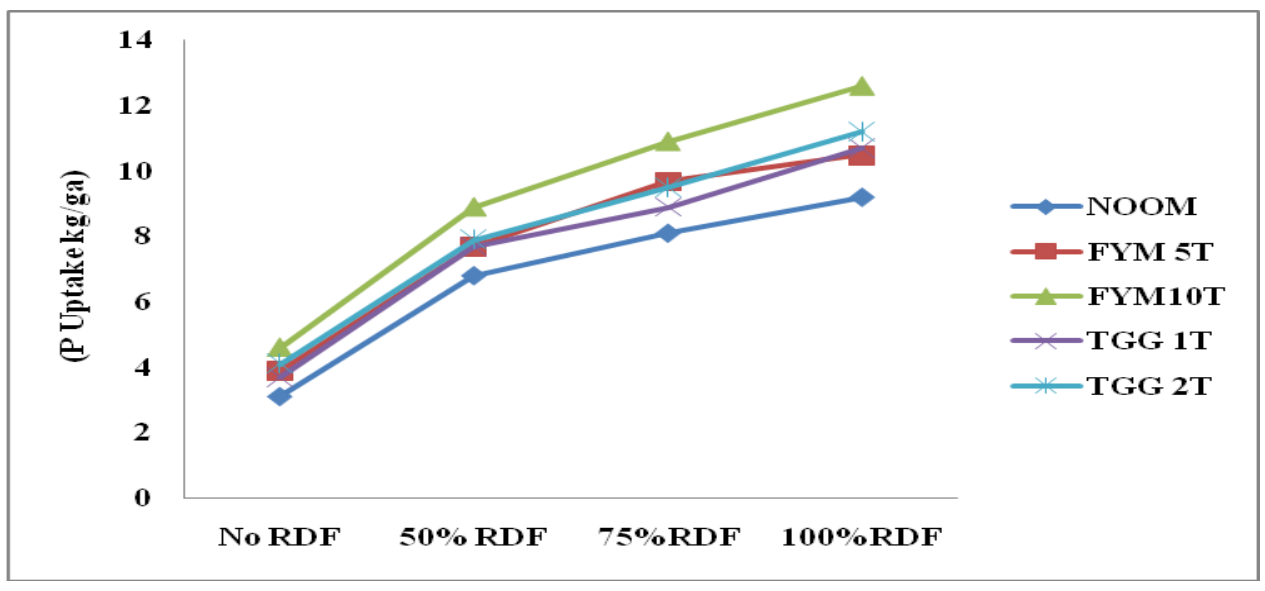

Figure.3 Effect of different organic manures on K-uptake of FCV tobacco

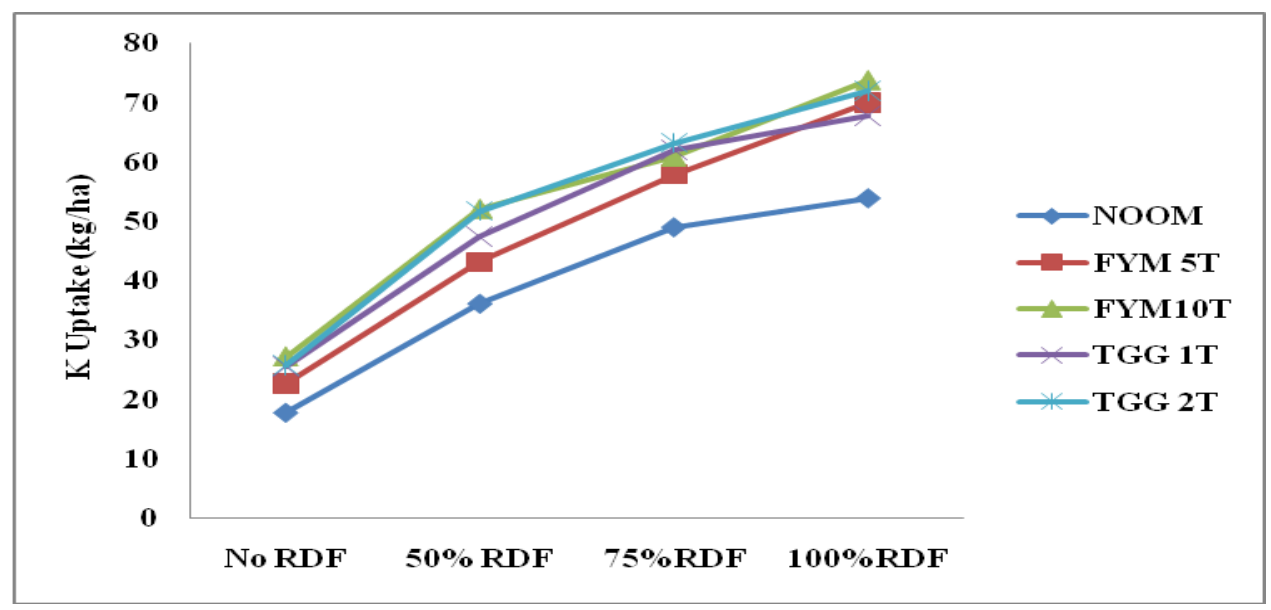


Among different fertilizer doses $100 \%$ RDF recorded highest nicotine content with 1.35 per cent. Increase in fertilizer doses increased the nicotine content significantly. Reducing sugars were not significantly influenced by different organic manure treatments. Increase in fertilizer doses over organic manures decreased the sugar content in all the plant positions.. The interaction between main plots and sub plots was not significant. Organic manures significantly influenced the chloride content in the lamina. In $\mathrm{P}$ and $\mathrm{X}$ position, application of TGG @ 2 t/ha showed significantly higher chloride content with 1.5 and 1.29 per cent, compared to Farm Yard Manure. Increase in fertilizer doses decreased the chloride content. Chlorides content in no fertilizer treatment was significantly higher compared to other fertilizer treatments (Table 5). Blaise et al., (2005) reported that FYM application has improved the yield and quality of cotton through nutrient supply and also maintains a healthy positive nutrient balance.

\section{Soil properties}

The soil properties analyzed did not show any significant differences among the organic manure treatments (Table 6).

Based on the yield, chemical quality, and nutrient uptake it can be concluded that application of organic manure is very much necessary for FCV tobacco cultivation in Northern Light Soils of Andhra Pradesh. Among the sources farm yard manure 10 t/ha was superior to Tata Geo Green. It can be concluded that application of organic manures irrespective of the source is very much essential for FCV tobacco grown in the light textured soils as the yield enhancement due to the organic manures is to an extent of 14 per cent without any significant effect on the chemical soil fertility parameters. Among the two sources the impact of the FYM is more pronounced $(8.2 \%)$ compared to TGG $(3.7 \%)$.
Hence, application of farm yard manure is very much essential for FCV tobacco in light textured soil in the event of non-availability of FYM, Tata Geo Green $\left(1 \mathrm{t} \mathrm{ha}^{-1}\right)$ can be used as a source of organic manure.

\section{Acknowledgement}

The authors are thankful to Rallies India Pvt. Ltd, Bombay, for supply of Tata geo green and financial support.

\section{References}

Blaise, D., Singh, J.V., Bonde, A.N., Tekela, K.V., and Mayee, C.D., 2005. Effect of farmyard manure and fertilizers on yield, fibre quality and nutrient balance of rainfed cotton (Gossipium hirsutum). Bioresource Technology, 96(3): 345-349.

Chiroma, A.M., Folouso, O.A., and Alhassan, A.B., 2006. The effects of land configuration and wood-shevings mulch on the properties of a sandy loam soil in northeast Nigeria. I changes in chemical properties tropicultura, 24: 129-134.

Dwivedi, B.S., Singh, V.K., Meena, M.C., Abir Dey, Datta, S.P. 2016. Integrated nutrient management for enhancing nitrogen use efficacy. Indian Journal of Ferilizers. 12(4), 62-75.

Gopalachari, N.C., 1984. Tobacco Indian Council of Agricultural Research, New Delhi. PP.327.

Gopi, R., Kalita, H., Avastin, R.K 2015. Organic management of tomato late blight in Sikkim Himalaya. In: compendium of abstracts of the $2^{\text {nd }}$ international conference on bio resource and stress management. ANGRAU \& PJTSAU, Hyderabad, 710 January 2015.

Harvey, W.R., Sta, H.M and Smith, W.C. 1969. In methods of determination of 
the chemical and physical constituents of Tobacco ICAR-CTRI. Tobacco Science XIII: 13-15.

Jablonska, C. R. 1990. Straw as an organic fertilizer in cultivation of vegetables. Part-II. Effect of fertilization with straw on the growth of vegetable plants. Hort, Abstr.,63-244

Jackson, M.L. 1973. Soil chemical analysis. Prentice-Hall of India Pvt. Ltd., New Delhi, India, Pp. 111-204.

Kamalakumari, K., Singaram, P. 1996. Parameters of maize as influenced by application of fertilizers and manures. Madras agri J., 83(1): 32-33.

Krishnamurthy, S., Uma Maheswara Rao, M., 1976., and Balagopal, K., 1972. Effect of continous application of organic manure, inorganic fertilizers and their combination on the yield and quality of FCV tobacco in black cotton soils of Andhra Pradesh. Indian J.agri.Sci.42:341-346.

Krishnamurthy, V., Mahadevaswamy, M., Rao, CCS., Reddy, PRS., 2007. Effect of continuous cultivation of FCV tobacco on fertility status of soils of periyapatna in Mysore district of Karnataka. Tobacco Research 33(1 \& 2): 63-66.

Muthuswamy, P., Santhy, P., Ramanathan, G. 1990. Long term use of fertilizer on soil fertility and yield of crops in integrated Inceptisol. J. Indian Soc. Soil Sci., 38(3): 541-542.

Shekoyan, G.K., 1970. Influence of organic and inorganic fertilizers on tobacco quality. Tabak. Moscow 3:19-21.

Sumathy, V., D.S.K. Rao. and D.S. Reddy., 2007. Effect of nitrogen and irrigation management on yield of sunflower (Helianthus annus L.) and on soil fertility. J.Res.Angrau 35(2):1-8.

Zheng, Hui-Min; Yong., Xue-Yen; He Xinhera; Hu., Ming-Geng; Huang., Shao-Min; Liu., Hua; Wang, Bo-Ren. 2011. Effect of long term potassium fertilization on crop yield and Potassium efficiency and balance under wheet- maize rotation in China. Pedosphere. 21.154-163.

\section{How to cite this article:}

Chandrasekhararao, C., D. Damodar Reddy, M. Anuradha, S.V. Krishna Reddya and Poorna Bindu, J. 2018. Effect of Organic Manures in Conjunction with Inorganic Fertilizers on FCV Tobacco Productivity. Int.J.Curr.Microbiol.App.Sci. 7(07): 269-281. doi: https://doi.org/10.20546/ijcmas.2018.707.032 